\title{
EML4/ALK Fusion Protein Variant 5b
}

National Cancer Institute

\section{Source}

National Cancer Institute. EML4/ALK Fusion Protein Variant 5b. NCI Thesaurus. Code C99740.

A fusion protein ( $671 \mathrm{aa}, \sim 74 \mathrm{kDa}$ ) that is encoded by the EML4/ALK variant $5 \mathrm{~b}$ fusion gene. This protein is comprised of the $\mathrm{N}$-terminal half of the echinoderm microtubuleassociated protein-like 4 fused to the entire cytoplasmic domain of the ALK tyrosine kinase receptor protein including the tyrosine kinase domain. 